\title{
春椎・春㖪疾患に伴う排尿障害について
}

\begin{tabular}{|c|c|c|c|c|c|c|}
\hline & & & & & & \\
\hline 井 & & 賢 & 治・野 & 村 & 一 & 俊 \\
\hline 橋 & 本 & 伸 & 朗・平 & 野 & 真 & 子 \\
\hline 福 & 元 & 哲 & 也・浦 & 田 & 伸 & \\
\hline & 藤 & 広 & 生 & & & \\
\hline
\end{tabular}

\section{Dysuria Attendant Upon Spinal Medullary Diseases}

\author{
Kenji I, Kazutoshi Nomura, Nobuo Hashimoto, Mako Hirano, \\ Tetsuya Fukumoto, Shinichi Urata, Hiroo Sato \\ Department of Orthopedics, Kumamoto National Hospital
}

\begin{abstract}
Spinal $\cdot$ medullary diseases may be complicated with neurogenic bladder. At our hospital we meacure pressure of bladder and study its diagnostic and thorapeutio usefulness in the cases of spinal-medullary diseases complicated with dysuria. In this paper we report three cases, in which neurological information of the bone marrow not obtainable with orthopedic imaging and clinical findings could be obtained by cystometry.

Cystometry is an auxilliary diagnostic method that can easily be done. We intend to use it positively in the future.
\end{abstract}

Key words : spinal·medullary diseases (脊椎・春䯣疾患), neurogenic bladder（神経因性膀胱）, cystometry (膀胱内圧測定), diagnosis and therapy（診断と治療）

\section{はじめに}

脊椎・脊髄疾患では, 神経因性膀胱を合併する場合 がある. 膀胱の機能検査としてその内圧を測定し蓄尿 及び排尿機能を観察することで排尿障害の面から神経 学的情報を得ることができるが当院では脊椎・脊䯣疾 患で排尿障害を合併している症例において膀胱内圧を 測定し，診断治療上での有用性を検討している. 今回, 膀胱内圧測定が診断. 治療を進める上で特に有用であっ た症例を報告する。

\section{対象及び方法}

対象 : 脊椎・脊䯑疾患で排尿障害を合併していた 13 例.（男性 9 例, 女性 4 例： 23 歳 $~ 93$ 歳: 平均 64
歳) 疾患は頸椎症性頸㵦症 5 例, 腰部椎間板ヘルニア 2 例, 腰部脊柱管狭窄症 2 例, 腰部圧迫骨折 2 例, 腰 部化膿性脊椎炎 1 例, 頸椎症性頸䯣症・腰部脊柱管狭 窄症 1 例, 腰部圧迫骨折・頸椎症性頸䯣症 1 例あった。

方法 : 排尿後仰臥位または坐位にて尿道から細いカ テーテルを挿入し CO2 $100 \mathrm{ml} /$ 分の速度で注入し， 膀胱内圧を測定して, 神経学的所見及び画像所見と比 較検討した。膀胱内圧測定により得られた結果は ICS (International Continence Society) の分類 ${ }^{3)}$ に準 じて診断した.

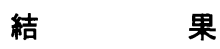

膀胱内圧測定の結果, 正常活動型膀胱 4 例低活動型 膀胱 5 例，過活動型膀胱 4 例であった．正常活動型以 
外の 9 例のうち 7 例 $(78 \%)$ は膀胱内圧測定による高 位診断と初診時のレベル診断が一致した。 13 例中 3 例（23\%）は膀胱内圧測定が診断・治療の上で役立っ たので報告する.

\section{症 例 提 示}

\section{症例 1) 76 才 男性}

主訴: 間欠性跛行.

現病歴: 平成 10 年 5 月左上下肢のしびれ感が出現 し近医を受診するもそのまま放置. 同年 12 月, 間欠 性跛行, 手指の巧緻障害, 体幹支持性の低下, 尿失禁 が出現したため来院した。

現症 : 右下肢麻痺，尿失禁 (尿意十).

神経学的所見: MMT は上肢では正常, 右下肢で 2 $\sim 3$. 両上下肢の知覚低下 $(6 / 10)$ と深部反射の方進 を認めた。

MRI 所見 : 頸部で多椎間にわたる脊柱管の狭窄が

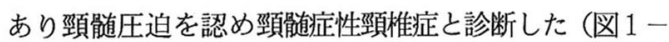
a). 腰部では第 3 , 第 4 腰椎, 第 4 , 第 5 腰椎部の 椎間の膨隆と黄色勒帯の肥厚が認められ春柱管狭窄症 と䛦断した (図 $1-b)$.
膀胱内圧測定: $\mathrm{CO}_{2} \quad 70 \mathrm{ml}$ 注入時に大きな無抑制収 縮が認められ核上型脊㕼障害と診断された (図 $2-a)$. 症状の責任部位は当初, 弛緩性麻痺等より腰部病変 が強く疑われたが膀胱内压測定により頸部病变による あのと判明した。

今回，頸椎症性頸䯣症に対し第 2 第 7 腰椎の椎弓 形成術（第 2 頸椎ドーム状骨切り，第 3 ～第 7 頸椎椎 弓形成）を行ったところ, 術後 1 日目に下肢の筋力の 改善がみられ 10 日目に平行棒内歩行訓練を開始した. 2 週間後に膀胱内圧を再検したところ無抑制収縮は著 名に改善していた（図 $2-b$ ). 術後 1 カ月にてリ八 ビリのため転院となった。

症例 2）51才 男性

主訴 : 両下肢麻㽻, 右肩痛.

現病歷：バイクで車と衝突し受傷. 第 2 腰椎の圧迫 骨折による両下肢麻痺及び右鎖骨遠位端骨折の診断で 近医より当院に搬送された。

神経学的所見: 両下肢の知覚脱失, 運動麻痺. 上肢 の筋力及び知覚は正常.

画像所見 : X-P で第 2 腰椎の圧迫骨折を認めた。

(a)

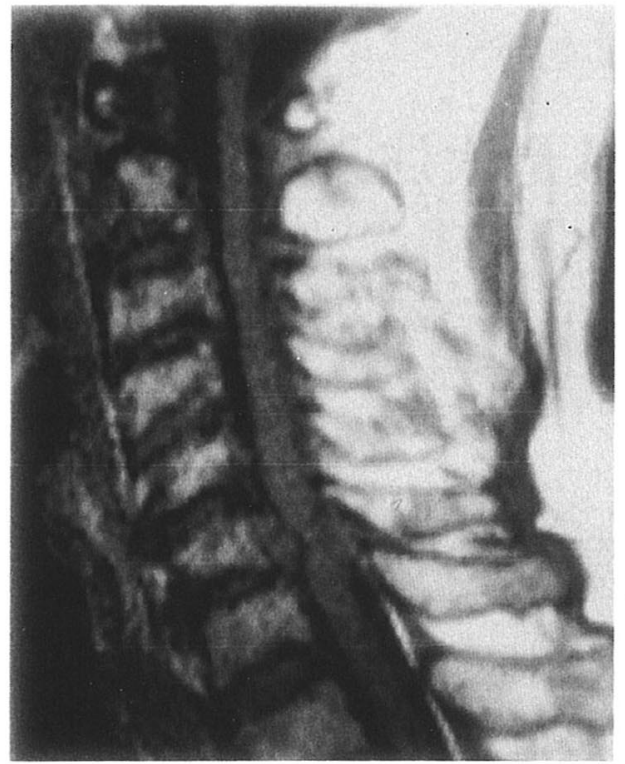

$\mathrm{T} 1$

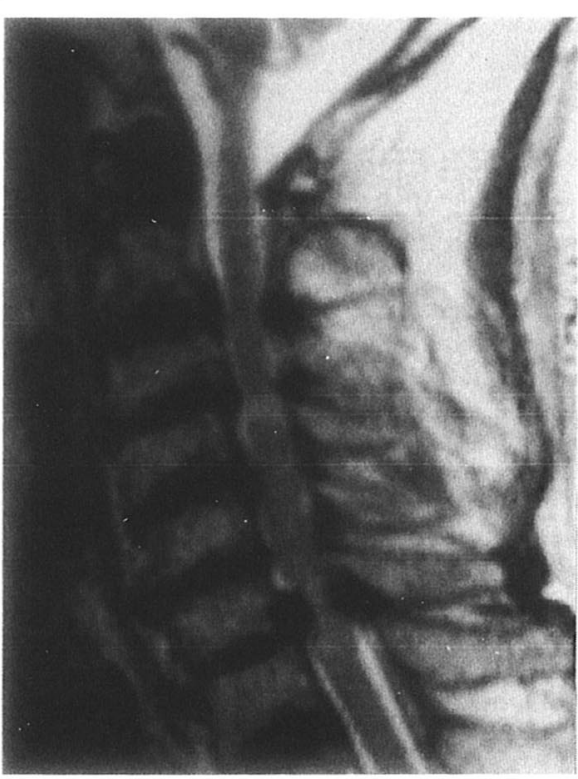

$\mathrm{T} 2$

図 1 症例 1 頸・腰部 MRI

多椎間にわたる canal stenosisによると思われる脊䯣圧迫を認める 


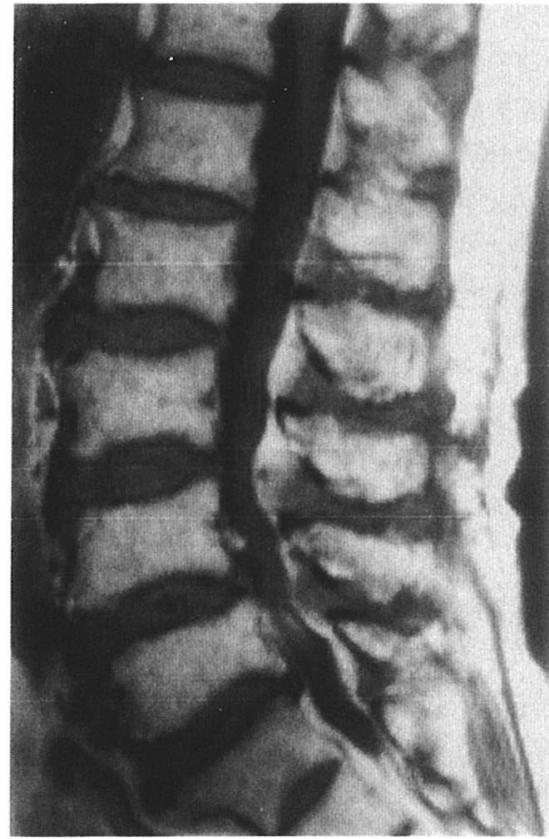

$\mathrm{T} 1$ (b)

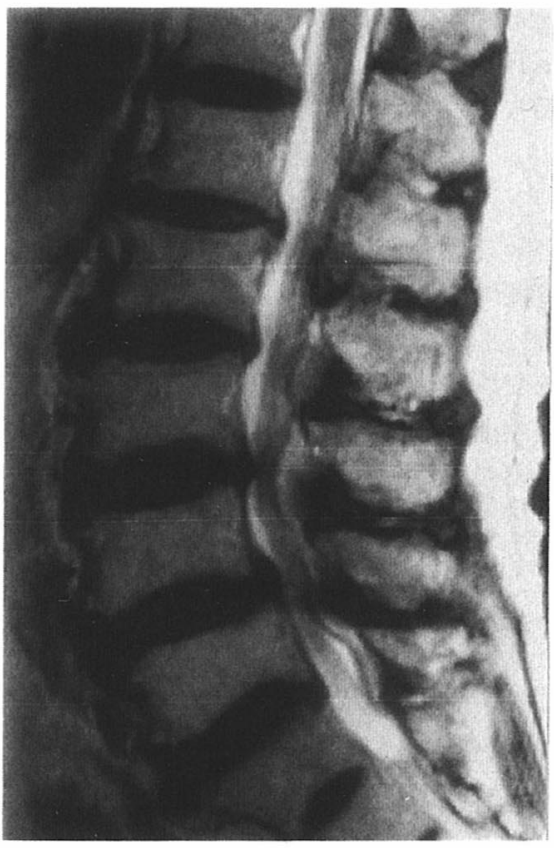

$\mathrm{T} 2$

L3/4，L4/5 に椎間の膨隆と黄色勒帯の肥厚あり Canal stenosis の所見を認める

(a) 術前

\section{初発尿意 $68 \mathrm{ml}$ 最大注入時 $89 \mathrm{ml}$}

内

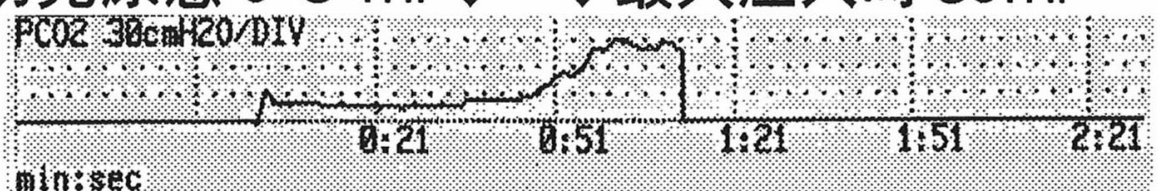

$\mathrm{CO}_{2} 70 \mathrm{ml}$ 注入時に大きな無抑制収縮を認める.

(b) 術後

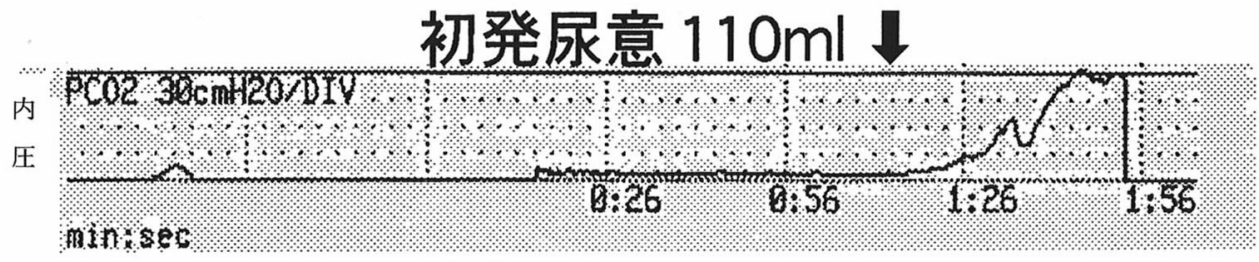

無抑制収縮は術前に比べ著明に改善した。

図 2 症例 1 膀胱内圧曲線 
MRI では第 2 腰椎の圧迫骨折は認めるものの第 2 腰 椎高位での脊㖪圧迫所見はなかった（図 3 -a）

膀胱内圧測定 : $\mathrm{CO}_{2}$ を $641 \mathrm{ml}$ まで注入したが尿意 はなく排尿筋収縮が消失しており無収縮膀胱（spinal shock）の所見を示した.（図 4-a )

そこでより上位の頸椎. 胸椎部の病変を疑い MRI を施行したところ第 6 頸椎の亜脱臼による頸喣圧迫所 見を認めた (図 $3-b)$. 頸椎レントゲンを再確認し た結果, 正面像ではわずかに第 6 , 第 7 頸椎の梀突起 間の配列異常か認められ (図 $3-c$ ) 側面像では第 6 , 第7 頸椎は肩の陰影に覆われて映っていなかった（図 $3-d)$. 初診時, 右鎖骨骨折部の強い痛みのために 頸部の症状についての訴えがなく, 当初, 頸椎での損 傷を考慮していなかった.

直ちに頸部椎間板摘出及び前方固定術, 第 $3-5$ 腰 椎の後方固定術を行った.

術後 20 日目には両足趾の自動運動がみられるよう になり,リハビリ目的で転院となった，半年後，当院 外来を受診時に再度膀胱内圧を測定したところ $\mathrm{CO}_{2}$ $148 \mathrm{ml}$ 注入にて初発尿意が出現し $270 \mathrm{ml}$ 注入時に最 大尿意の自覚があった. 膀胱反射性収縮, 無抑制収縮 はなく膀胱コンプライアンスは良好であった（図4b). 残存している排尿障害は第 6 , 第 7 頸椎より第
2 腰椎の圧迫骨折による可能性が強いと思われる.

症例 3）47 男性

主訴：両下肢麻痺，尿閉。

現病歴 : 早期胃癌の術後感染 (MRSA) による腹 腔膿瘍を苦に 3 階から飛び降り受傷．その 2 日後に完 全尿閉となり緊急手術の適応ありとのことで当院に紹 介入院となった.

神経学的所見: 両下肢筋力低下 (MMT3), 知覚鈍 麻, Frankel 分類 C

MRI 所見 : 第 3 腰椎の圧迫骨折による脊䯣圧迫を 認めた（図 5 ).

膀胱内圧測定 : 初発尿意の遅延はあるものの膀胱内 圧は比較的保たれており（図 $6-\mathrm{a}$ ) 不全麻痺と診断 された.

膀胱機能の残存が確認されたため腹腔膿瘍の鎮静化 を待って 2 力月後に第 2 第 4 腰椎の後方固定術を行っ た.

術後, 両下肢筋力は MMRT 4 ～ 5 と改善が認めら れ, 膀胱内圧測定む $\mathrm{CO}_{2} \quad 150 \mathrm{ml}$ 注入時に排尿反射が 認められ初発尿意遅延の改善がみられた (四6-b). 慢性期の神経因性膀胱と考えられ尿道留置カテーテル を抜去し排尿訓練を開始した。 (a)

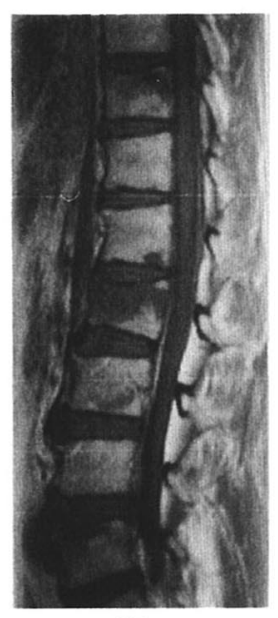

$\mathrm{T} 1$

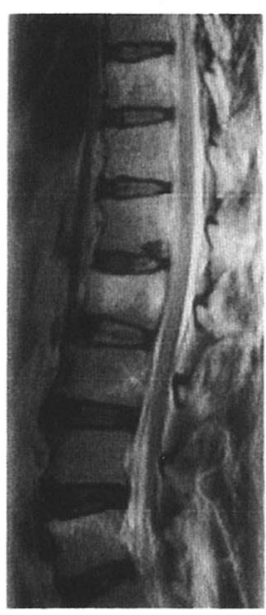

$\mathrm{T} 2$

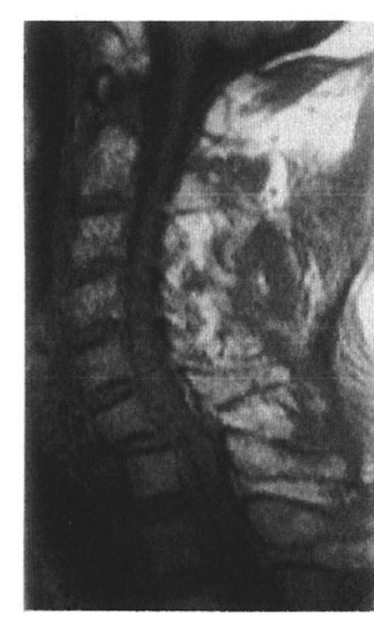

$\mathrm{T} 1$ (b)

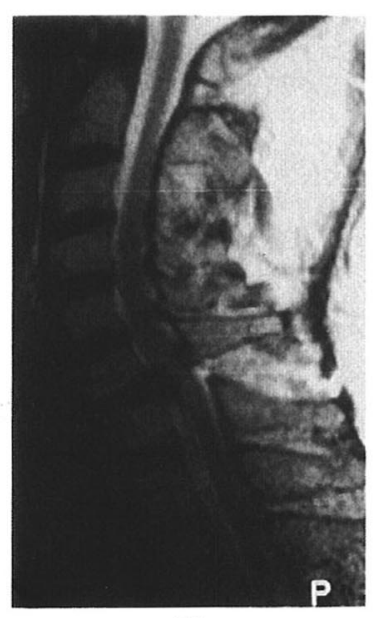

$\mathrm{T} 2$

L2 の圧迫骨折を認めるが脊䯣圧迫は認めない

図 3 症例 2 頸・腰部 MRI 
(c)

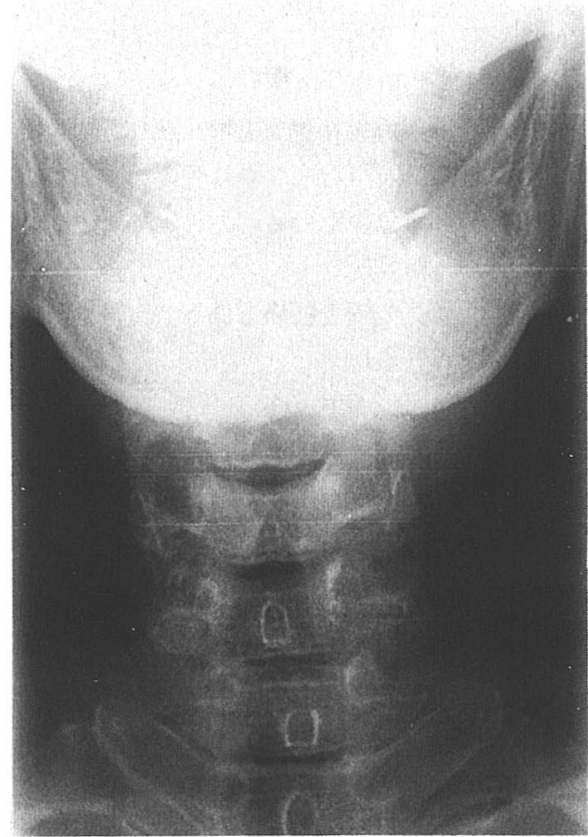

前 後 (d)

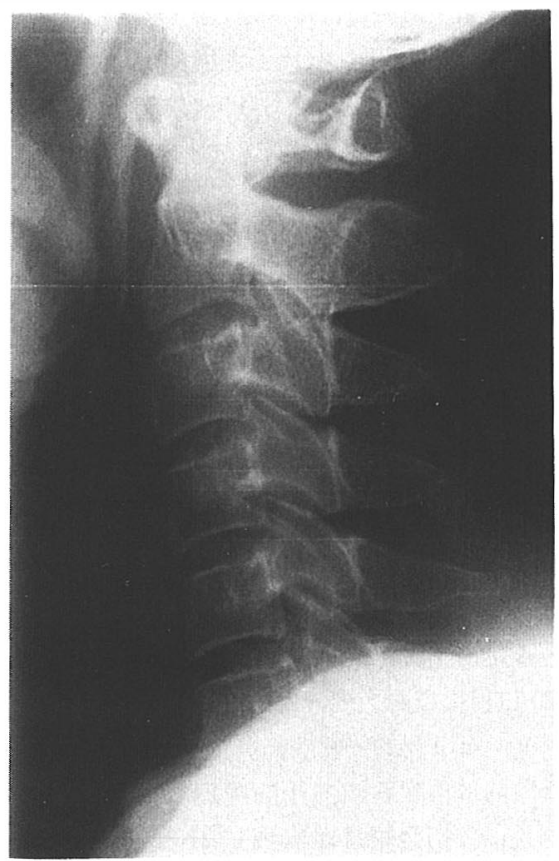

側 面

図 3 (症例 2 ) 頸部単純 $X$ 線

c : わずかに第 6 ・第 7 頸椎の棘突起間の配列異常が認められる

$\mathrm{d}$ ：明らかな所見は認められないが第 6 ・第 7 頸椎が肩の陰影に覆われて映っていなかった

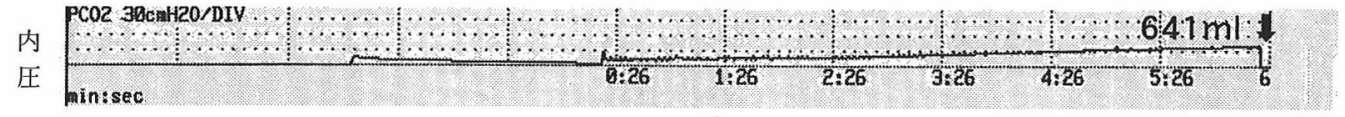

図 4-a 症例 2 膀胱内圧曲線（術前）

$\mathrm{CO}_{2}$ を $641 \mathrm{ml}$ まで注入するす尿意はなく排尿筋収縮が消失していると考えられる.

考察

通常, 頸骾圧迫疾患における神経因性膀胱の発生頻 度は約 30\% 50\% 1 1 4) 5), 腰部脊柱管狭窄症の排尿障 害の頻度は $11 \%{ }^{6)} \sim 21 \%{ }^{9)}$ との報告があり，頻度的 には決して少なくないといえる。しかしながら排尿障 害を合併している脊椎・脊䯣疾患での麻痺レベルや膀 胱内圧変化に着目した報告は少ない ${ }^{8)}$.

我々は尿流動態検査法は高位診断および神経因性膀 胱の病態把握の上で有用な検查法であると考える ${ }^{8)}$. 正常な排尿機能は蓄尿と排尿の 2 つの相で構成され，
健常人では蓄尿期の膀胱内圧はほぼ一定で, 最大膀胱 容量時に排尿を命じると初めて膀胱内圧が上昇する. 膀胱機能異常は神経の損傷部位が，橋排尿中枢と仙䯣 排尿中枢（第 12 胸椎/第 1 腰椎レベルに相当）のそれ ぞれ上位か下位かで(1)脳幹部より上位の障害, (2)核上 型障害，(3)核・核下型脊䯣障害に分類することができ $ろ^{8)}$. さらに核上型は発症後の時期によりショック期, 回復期, 慢性期に分類される. 病変部位の高さ（高位 診断）により核上型と核・核下型に，損傷の程度によ り完全麻痺と不全麻痺に分類される ${ }^{10)}$. 斎藤ら ${ }^{7)}$ は仙 䯣排尿中枢より上位の核上型損傷では受傷直後, 膀胱 


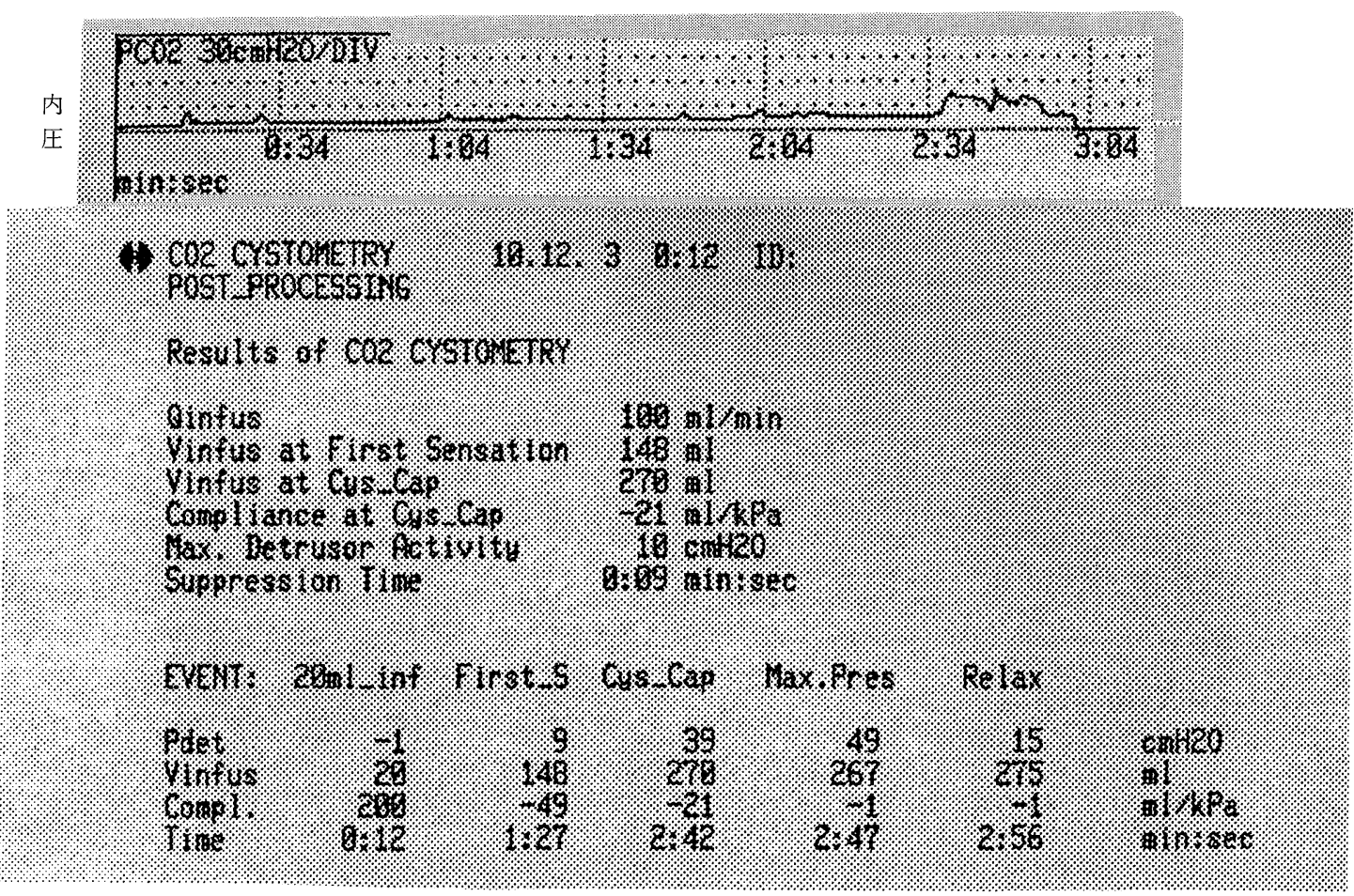

図 4-b 症例 2 膀胱内圧曲線（術後 6 ケ月）

$\mathrm{CO}_{2} \quad 148 \mathrm{ml}$ 注入にて初発尿意が出現し $270 \mathrm{ml}$ 注入時に最大尿意の自覚があった.

は完全弛緩型となるものの，その後慢性期に入ると反 射性の無抑制収縮が発生する一方，仙䯣排尿中枢以下 の核・核下型損傷では膀胱の反射性収縮は永久に消失 するとしている，当院では簡便な $\mathrm{CO}_{2}$ 注入による膀 胱内圧測定で核上型障害, 核・核下型脊䯣障害の判定 を行っている．鈴木ら ${ }^{8)}$ は脊䯣損傷患者において 24 時間膀胱内圧測定を行った結果, 診断・治療を決定す る上で有用な検査法であると述べている，我々も今回 13 例中 3 例 $(23 \%)$ において膀胱内圧測定が診断・ 治療上有用であった. Dagiら ${ }^{2)}$ は馬尾神経圧迫疾患 における神経因性膀胱について頸椎疾患む合併してい る例があり一概に腰椎狭窄部以下の障害と断定はでき ないと述べているが, 今回我々の症例においては, 頸 椎病変か腰椎病変かの診断が可能であった. 症例 1 で は脊䯣圧迫疾患に対して症状の責任部位として腰部病 変が強く疑われたが膀胱内圧測定により頸部病変によ るものと判明し手術部位決定に役立った. 症例 2 では 頸椎損傷の見逃しが膀胱内圧測定にて判明し損傷の高 位診断に役立った。症例 3 は膀胱の完全麻痺と思われ た症例で膀胱内圧測定を行い膀胱機能が保たれている
ことが分かり緊急手術の回避に役立った。

脊椎・脊䯣疾患に於ける障害の高位診断は, 知覚, 筋力, 反射等の検査が基本であるが検者及び患者の主 観がある程度影響する可能性がある．その点膀胱内圧 測定は他覚的な検査であり障害高位そのあのが反映さ れる。

我々は今回の経験で排尿障害の面から簡便に 5 分位 の検查で多くの神経学的情報を得ることができる膀胱 内圧測定は有用な補助的検査法の 1 つと考える. 今後 屯積極的に活用していく方針である.

$$
\text { ま と め }
$$

1. 脊椎・脊髄疾患において膀胱内圧による診断・ 治療上での有用性を検討した。

2. 膀胱内圧測定が特に有用であった 3 例について 報告した。

3. 一般的な整形外科的画像所見及び臨床所見のみ では得られない脊髄の神経学的情報を得ることができ た。

4. 13 例中 3 例 $(23 \%)$ に有用であったことより 


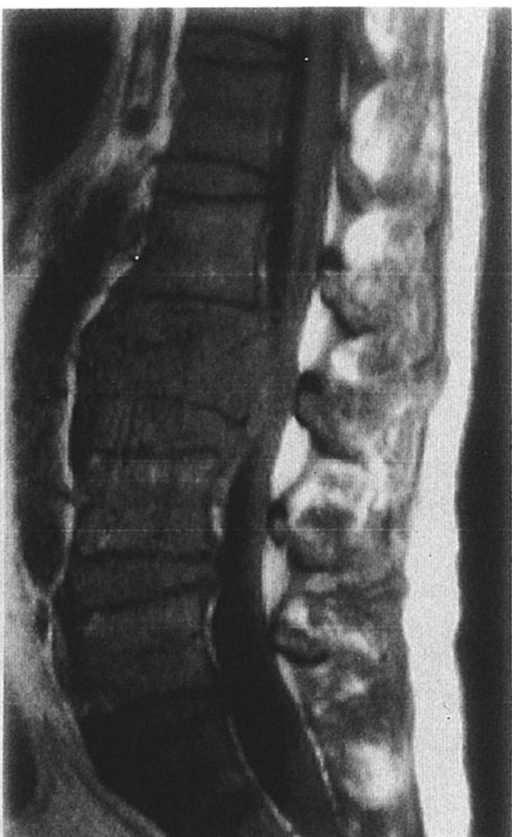

T1

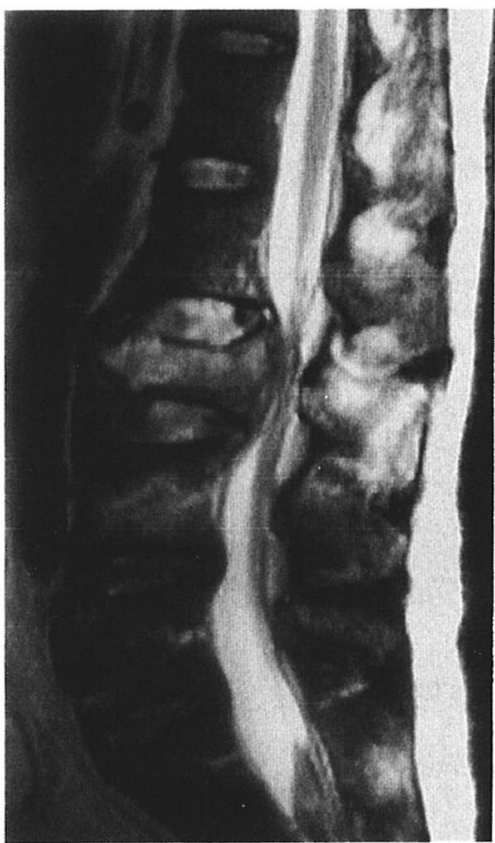

$\mathrm{T} 2$

図 5 (症例 3 ) 腰部 MRI

第 3 腰椎の圧迫骨折による脊䯣圧迫を認める

(a) 術前

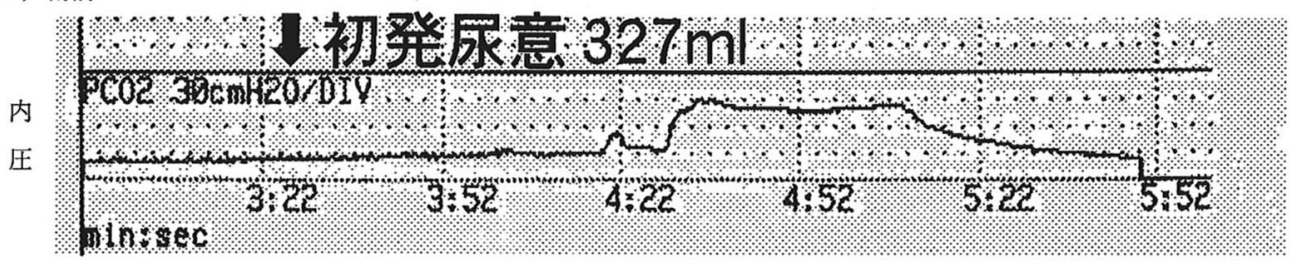

初発尿意の遅延が認められる

(b) 術後

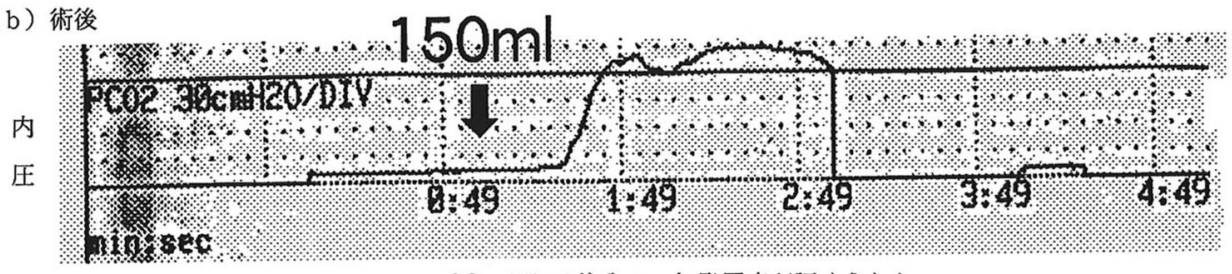

$\mathrm{CO}_{2} \quad 150 \mathrm{ml}$ 注入にて初発尿意が認められた

図 6 （症例 3）膀胱内圧曲線 
膀胱内圧測定は簡便におこなうことができる補助的診 断法として今後積極的に活用していく方針である.

\section{参 考 文 献}

1）安藤正男：頸䯣圧迫疾患に合併する神経因性膀胱につ いての臨床的研究. 日秘尿会誌 $81: 243-250,1990$ 。

2) Dagi : TF, Tarkington MA, Leech JJ : Tandem lumbar and cervical spinal stenosis. J Neurosurg $66: 842$ $849,1987$.

3）服部孝道，安田耕作：神経因性膀胱の診断と治療第 2 版. 医学書院 : 76-84, 1990.

4) Hattori $T$, Yasuda $K$, Sakakibara $R$, et al : Micturitional disturbance in ossification of the posterior longitudinal ligament in the cervical spine. $\mathrm{J}$ spinal disorder $3: 285-287,1990$.
5) Hattori T, Sakakibara R, Yasuda K, et al : Micturitional disturbance in cervical spondylotic myeropathy, J spinal disorder $3: 16-18,1990$.

6) Kneda K, Kazama H, Satoh S, et al : Follow up study of medical facetectomies and posterolateral fusion with instrumentation in unstable degenerative spondylolisthesis. Clin Orthop 230 : 159-167, 1986.

7）斎藤政彦, 近藤厚生 : 脊䯣損傷と排尿障害, 排尿障害 プラクティス, vol2 No3, 1994 .

8）鈴木 亨, 高坂 哲, 米本恭三: 脊䯣損傷患者におけ る 24 時間膀胱内圧測定法の研究, リハビリテーション 医学 $36: 172-179,1999$.

9）辻 陽雄, 伊藤達雄, 玉置哲也, 他：腰部脊柱管狭窄 症，間欠性跛行，整形外科 Mook 41：109-119，1986。

10）吉田 修, 並木幹夫：神経因性膀胱外来. 88-96. 石 浦嘉之, 東京, Medical view, 1998. 